\title{
The Uses of Gong Suling in Ngemban Rare Composition
}

\author{
Visvam Bhara Prasad ${ }^{1}$, I Komang Sudirga ${ }^{2}$, Hendra Santosa ${ }^{3}$ \\ ${ }^{123}$ Department of Seni Karawitan, Faculty of Performing Arts, \\ Institut Seni Indonesia Denpasar \\ email: 1 wiswajos@gmail.com , ${ }^{2}$ komangsudirga@isi-dps.ac.id, \\ hendrasnts@gmail.com
}

\begin{abstract}
ABSTRAK
Komposisi Ngemban Rare yang menggunakan Gamelan Gong Suling ini menggambarkan kenangan masa kecil dengan berbagai sikap. Karya ini terinspirasi oleh seseorang yang merawat anak yang sedang menangis. Bahkan, saat ini sebagian besar orang tua mengajarkan hal-hal yang salah kepada anak-anak dengan memfasilitasi mereka sebelum mereka cukup dewasa sehingga membuat karakter anak menjadi tidak baik. Komposisi ini terdiri dari tiga bagian, yaitu menggambarkan suasana fenomena mengasuh anak-anak, mengasuh anak-anak dengan menyanyikan lagu-lagu anak-anak tradisional, mengajar anak-anak dan memperkenalkan budaya sejak usia dini, dan menanamkan disiplin dan karakter yang baik, agar tidak menyesal kemudian. Pembentukan ciptaan karya ini mengacu pada proses penciptaan karya seni yang diklarifikasi menjadi tiga tahap, yaitu tahap eksplorasi, tahap improvisasi, dan tahap pembentukan.
\end{abstract}

Kata kunci: Ngemban Rare, gong suling, anak-anak, komposisi musik.

\begin{abstract}
ABSTRAK
The composition of Ngemban Rare that uses Gong Suling Gamelan is about childhood memories with various attitude. This work is inspired by someone whom care for a crying child. In fact, nowadays most of the parents teach wrong things to children by facilitating them before they are mature enough thus making the children character becomes unkind. This composition consists of three parts, namely describing the atmosphere of the phenomenon of caring for young children, caring for children by singing traditional children's songs, teaching children and introducing culture from an early age, and instilling good discipline and character, so as not to regret later. The formation of creation of this work refers to the process of creating works of art that are clarified into three stages, namely the exploration stage, the improvisation stage and the forming stage.
\end{abstract}

Keywords: Ngemban Rare, gong suling, children, music composition. 


\section{INTRODUCTION}

Humans will go through the process or stages of life, starting from the process of birth, life process, and death. This happens naturally and everyone will go through the process. "To realize the ideals of Hindu Dharma achieving Jagaditha and Moksa, every Hindu is taught to achieve four life goals. The four life goals of life are called Catur Purusartha. The four life goals can be achieving only by go through life stages as with human growth itself. This stages are called Catur Asrama. (Wiana, 1997:53). Catur means four and Asrama means stages or level. Catur Asrama meaning 4 stages of life that must be lived in earnest to reach moksa. As for some Catur Asrama stages, namely brahmacari, grihasta, wnaprasta, sannyasin or bhiksuka.

Children can be the pride of parents not only in childhood but also when children are adults because of their success. To make a child grow and develop well in Bali in particular, a ceremony is carried out from the time the baby is still in the womb, even until the age of 17 years and finally the marriage ceremony which is all called a series of ceremonies Manusa Yadnya. Entering a series of life process, especially when he was a toddler, in this process the child is like a blank paper that still does not contain anything, but if it has been exposed to something good then the nature and behavior of children will be good, and vice versa. In this phase, it should be an example of good things to the child, because of his imitative nature.

In growth process, children will experience sickness, sadness, and crying. If the child is crying, usually the parents will pick up the child while singing to them, from singing children's songs to spontaneous songs to soothe the child. Children from 1 to 5 years old usually active and at that time if they are sick or not feeling well, sleepy, usually psychological of children will changing become sad, crying, and often crying, if this things happening parents will sing children's songs or spontaneous songs. Composer experience (Visvam Bhara Prasad) himself while care for a child whom crying because he was left to work by his parents, at that time the child cried screaming, coincidentally composer at home alone was forced to calm the baby who was crying by picking him up and gave milk and singing spontaneous songs like "Curik-Curik", "Meong-Meong", and others act so the baby whose crying will calm. At the end, the baby stops from crying and fall asleep, previous experience happened to composer and found same things likely to happen. When composer trying the 
same action according to the previous experience turns out it did well, and proving that traditional song are very suitable to children psychology.

In fact, in this ages many parents who have left the old way to soothe babies, have a great effect because the times are different, nowadays mostly parents soothe their children with taking them to places or children playground, taking them to supermarket, and the most composer see is giving their child using a mobile phone or nowadays called a smartphone. Many children addicted to smartphone, and from personal experience seeing children crying because 'they want' to play with smartphone, but their requested are neglected by their parents, after a long time of crying at last the parents giving the smartphone to the children whose been crying for so long, and many example of same cases. This situation indicates that now there has been a shift in how to calm the child by giving a cellphone or taking them to a playground, which composer thought is not appropriate because it makes the child addicted.

Facing the fact, composer is not pessimistic because the composers still see some parents who are still using the old way to care for their children who are crying or fussy. Usually to soothe their babies who are crying, especially in Bali parents of fussy babies often sing sekar rare songs like "Meong-Meong", "Curik-curik", even songs or songs to spontaneously soothe their babies deep sleep in the lap of his parents who are still sleeping their children. Moving on from that experience the stylist was inspired to express personal experience that was used as a concept in creating the final project composition, from that experience the stylist also tried to raise the phenomenon of life, in a musical composition with a flute gong entitled Ngemban Rare. The meaning of the word ngemban means to invite, to carry and the meaning of the word rare means a child or a child. So the meaning of the word Ngemban Rare is to take care of, which in Balinese terms are called "ngempu".

Ngemban Rare was performed in the area of Taman Ayun Temple, Mengwi, Badung. This piece contains 12 minutes 20 seconds supported by 25 musicians including the composer / composer (Visvam Bhara Prasad) himself. The player who supporting this composition is from the Shiva Art community. Before doing the first practice, the composer call them to do a meeting for the purpose of supporting the exam. The results of the meeting are community members or supporters ready to 
supporting this pieces. After that, a joint prayer was held to determine a good day so that it would be facilitated in the practice process.

\section{COMPOSITION METHOD}

The creativity process in realizing a work of art is not easy, therefore it needs a long and thorough preparation. At the time of composing, what determines success in realizing the piece is the process. A good process produces good works, basically artists work on or make pieces usually in accordance with their personal experiences and also the ability of supporters. In addition to supporting factors, the creativity process in realizing this piece is also very dependent on procedural systematic and composition method. The composition method consists of at least a stage of exploration, a stage of experimentation (improvisation) and a stage of formation (Agus et al, 2018: 99; Garwa, 2009: 43).

In the assessment process, the first step taken by the composer is to determine a good and clear idea. The idea of Ngemban Rare is the result of the analysis and observation of the composer when he sees the phenomenon of the lives of young children today. The interesting thing for the composer is the difference in the character of the children of the past and present. In accordance with the times, in the old days children who were fussy or crying were usually held and sung spontaneity songs to calm the child, but in today's children who are crying or fussy are usually given facilities such as cellphones, providing online games that make children become addiction. The experience of the composer looks at the differences in the children character's beforehand and children today, after determining the idea of the composer whom showing the media revealed that will be used, the composer chooses to use the gamelan distilled gong to realize this claim. The next preparation is to contact and find players to support this composition by observing and contacting them by telephone. After gathering players, composer choosing the first day of practicing and doing Nuasen (the holy ritual of the first day of practicing and at the same time conducts joint prayers to request the successful running of the project).

The obstacle begins by finding supporters who have been approved successfully. From the initial meeting to the incomplete practice process. Some of the players are working, so the clash of time makes never compact the claimants to practice. Choosing to practice at night is also not good because some players 
performing in the Bali Arts Festival that year (2018). Because of that, the composer arranges practice every Monday, Wednesday, Friday, and Sunday at 16:00 to 18:00.

In the exercise process the constraints experienced are the busyness of each players. There are some players who have worked, and there are also some players who go to school, in addition there are some players who will take the National Examination. Even though composer still continue to do the exercises so that later they will not be lack of time, the players whom already came still doing the exercise process so that there will be no lack time. The first process of exercise has started since the end of February, precisely on February 25, 2018. Another exercise obstacle is during the Nyepi day, just before Nyepi, exactly two weeks before the holiday, the exercising process cannot run due to the busyness of each players to support each banjar starting from the bustle of Melasti, busy making ogoh-ogoh, and so on. The exercising process is closed for two weeks after the Nyepi holiday again and continues to do exercise as usual on Monday 19 March 2018.

The stage of formation (forming) is the end of music composition Ngemban Rare that is a complete musical composition. The parts are put together into a unified whole form, beforehand the composer has been listening or inspired by some references and at last composer created this piece containing mp3 and video. From observing and listening to pieces that have been obtained by learning references, namely works entitled "Sekar Gayot", "Manik Pering", "Ne Nu Nak Nik", "Warna Warni Anak", "Walking in the Garden", composer get inspiration and reference to realize this piece Ngemban Rare. After that, there is writing guidance and guidance of music piece in order to get suggestions, and motivation so that this composition can be made complete.

To strengthen this piece, composer doing the finishing stage, to smoothes out, and into the character of this piece. Team work of each players is needed because through this whole process, composer and players needs 'feeling of one soul' and how to feel the rhythm of this piece when going on a stage and bring this composition with confidently, so the message of 'Ngemban Rare' is delivered well. After that composers made this piece permanently or final so there's no more changes, from small part to part so there will be internalization, deposition and appreciation of this composition. 


\section{DISCUSSION}

It has been stated that Ngemban Rare is a musical composition in the form of percussion creations using gamelan gong suling. The theme raised in this piece is to raise the phenomenon of the way of caring for children in ancient times and today. The reason why the composer raised this theme is to make parents aware of educating their children so as not to facilitate children from an early age by only providing mobile phones and online games. This theme is the basis of the formal object piece. The structure uses parts in which each part describe a narrative impression or atmosphere about the world of children arranged into three parts, the first part, the second part, and the third part.

Came up with this idea, the composer realized this piece with gamelan gong suling. This musical piece element uses three parts, in which in each part, composer uses an impression or atmosphere to describe parts per part. Ngemban Rare is in the form of percussion creations with 22 players including the composer, players of this compostion are from the Shiva Art community whose address is in Penarungan Village, Mengwi, Badung. This piece lasts 12 minutes 20 seconds and is performed at Taman Ayun Temple.






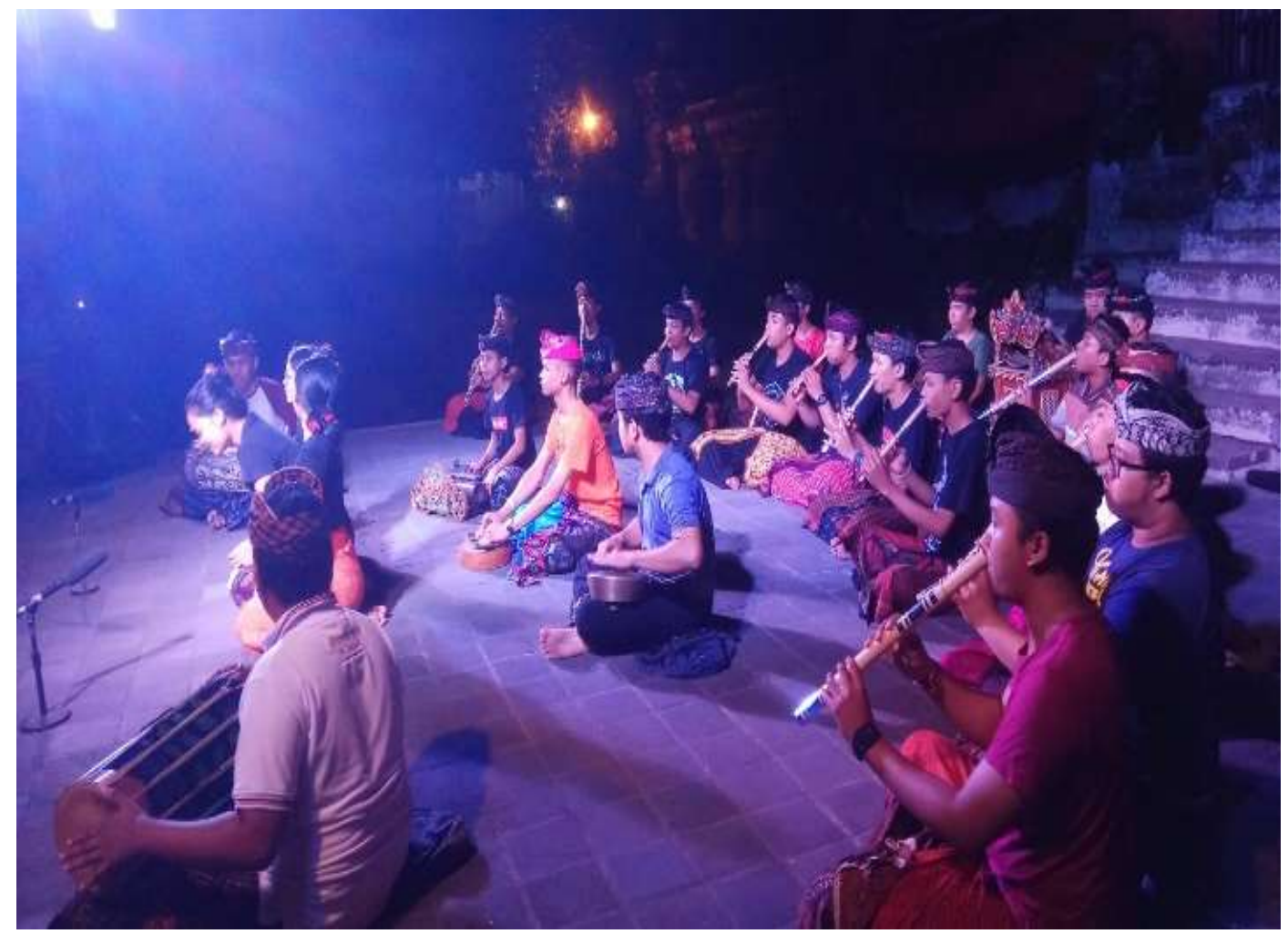

Picture 1 dan 2.

Dress Rehearsal and Performing Ngemban Rare in 2018

(Documentation: Pande Kurnia Adnyana).

\section{Structure Pattern Analysis}

In this first part, composer imagines how the behavior of a child who is still cute and adorable, which in daily life is adorned with laughter and usually a child curiosity about something so big. Sincere, innocent, cheerful and innocent like white paper that has not been touched by ink is the nature of small children. For this reason, the musical language is to process jegogan and gong flutes and to fill in the vocals that follow the melody.

The first part of Jegog's flute is accompanied by gong blows and gentorag sounds along with vocals that follow the melody. In this section, processing vocals that follow the jegog flute in this section there is no repetition, the application in this section illustrates how the nature of children who are still like white paper that has not been touched by ink. The flute instrument plays together and interspersed with melody techniques between jublag flute, jegog flute with pemade flute, besides that there are also some empty spaces filled with vocals at the end of the sentence vocal 
songs that are inserted only follow the flute melody and there are some vocals that also contain vocal words, flute technique uses the Ngempyung technique to produce harmony. This section describes how young children whose curiosity is very large towards something, composer cultivates harmony is also interspersed with vocals when there are empty spaces. In this section there is a special vocal section that describes how parents who hope their children are useful to society.

The second part illustrates how child psychology has changed. They began to fuss and cry, because usually small children get bored with the situation. Psycholigical change so quickly, in the second part is described a child who has been crying and hard to calm. Parents struggle to carry and give them milk to calm the child. This section raises a phenomenon that often occurs now where children who are not old enough have been facilitated by their parents excessively, this makes the character of children is not good. In its musical language, it processes harmony on the flute and also includes vocals. Jublag flute and jegog play predetermined melodies, pemade flute plays the ubit flute and suir flute plays ngewilet (playing improvisation in accordance with predetermined melodies). The vocal processing in this section is purely the result of the experience of composer who had previously experienced took care of a small child and turns it into a melody processing which, according to composer, was in accordance with the impression that the child was being care of. Transition into part three, the jegogan flute plays using the ndeng cover, while the jublag flute plays using the cover and composer tries to harmonize from the combination of the two covers that play together, while in the flute the player plays the technique of playing the ngubit flute.

This third part describes parents who are aware on educate their children and how they have been wrong and returning to using the way of their parents used to educate them and calm the fussy children. In part four, composer will use vocal or singing songs that are impressed to tame the child who is crying according to the experience of composer before. Part four as the last part of this piece or ending of this composition. Part four ask the parents to educate their children in a good way, or to not provide something or facilities before the child is old enough to instill good character. Entering the third part, the drum kendang beat enggage with palegongan kajar giving accents to continue to the next section which is connected to the 
composed melodies. The last part of this piece processing melodies in which uses techniques between jegogan flute, jublag flute and pemade flute playing mutually.

\section{Aesthetic Analysis}

"Rare Ngemban" is a musical composition inspired by the phenomenon of 'how to educate children' in ancient times and today which can contain parenting that is adapted to the era to produce different characters. In its processing, composer processes musicals that are not-according to experience and the ability of composer to convey the messages conveyed in this piece.

In the structure of art there are four basic things that cause beauty, namely complexity, dominance, unity, balance. Aesthetic properties according to (Djelantik, 1990: 32) also included this piece as "unity (wholeness), dominance (protrusion), balance (balance)" in which this is done so that the musical work Ngemban Rare can be enjoyed. In Ngemban Rare, composer is very concerned about the wholeness of this composition, the wholeness of the beginning to the end of this piece, in this piece the protrusions achieved are protruding harmony, melody processing, tempo processing, and accentuating each part so that the impression in each part is conveyed.

The complexity of this piece is seen in the processing of the melody, the tempo and the most important thing is the music feeling, how to feel the song that is delivered so that the atmosphere to be conveyed is achieved, apart from that ngubit flute is quite complicated e according to the composer with a faster tempo than the melody, the difficulty of the flutist when opening the flap cover with a rather fast tempo sometimes makes mistakes in exercising process but composer tries to find until he is accustomed to playing a faster tempo.

Prominence (dominance) in this piece is found in the melodies whose playing techniques that are flat, so it will produce harmony. In addition, composer accentuates the inspired vocals when calming a crying child. There are also highlighting the jublag flute and jegog flute using different covers but playing together, and included drums accents. The unity of this piece from the first to the last part is a connecting bridge, the integrity of this piece and the final examination so that the messages Ngemban Rare can be conveyed. 
In addition, from the first to the last part of this piece becomes a frame in the whole composition work. In this piece, the question balance is how processing all instruments that get the same portion so that all instruments used get the right room or portion. Ngemban Rare also uses vowels, the most important thing is how to play the flute at a fast tempo composer and supporters find difficulties initially but from time to time practice finally find or get used to the right way to achieve balance in the work.

\section{Material Analysis}

Material analysis is an important element of Ngemban Rare. This musical composition is formed based on musical elements such as melody, rhythm, tempo, harmony, and dynamics, also formed by some material that reinforces vocal processing that describes the atmosphere take care of young children.

All instruments in Ngemban Rare are (1) Four Jegogan Flute. (2) Four Jublag Flute. (3) Four Pemade Flute. (4) One Petit Flute. (5) A pair of Kendang Krumpungan (Lanang-Wadon). (6) One Ricik Ceng-Ceng Instrument. (7) A laughter instrument. (8) One Timbung instrument. (9) An instrument of Kajar Pelegongan. (10) One Klenang instrument. (11) An instrument of Gong Pulu (Bladed Gong). (12) A Gentora instrument.

In this piece, the role of melody is very necessary where in its application composer uses melody to describe the desired impression or depiction of the atmosphere. Basically, rhythm can be divided into several forms including metric rhythm (steady rhythm), melodic rhythm (rhythm form which is the development of melodic patterns) and rhythmic rhythm (rhythmic form that emphasizes the rhythmic patterns that display rhythmic patterns complicated impression). Tempo in this piece which includes: slow, medium and fast tempo. In Ngemban Rare, the tempo element is very important because the tempo plays the song from the first to the end of the song, each part in this piece has a different tempo. Harmony arises due to the combination or several unequal tones or the term in Balinese is often called the ngempyung technique, which means the combination of tones is not the same but produces a pleasant sound. In Ngemban Rare, composer uses many elements of harmony in the first part so that the atmosphere or impression can be conveyed. 
Furthermore, the dynamics are important in music pieces so that art/music does not seem monotonous, in addition dynamics as an expression in the hope, concerning the accent on playing the technique of each instrument, as well as short length of the song performed to produce a dynamic impression in a work of art.



Picture 3.

Instrumen Setting of Ngemban Rare Composition

(Documentation: Pande Kurnia Adnyana).

Detail:

1. Kendang

2. Gerong

3. Timbung

4. Suling Petit

5. Ceng-ceng Ricik

6. Kajar Palegongan
7. Suling Pemade

8. Suling Jublag

9. Suling jegog

10. Gong Pulu

11. Tawa-tawa

12. Klenang dan Gentora.

\section{Performing Analysis}

This composition as final assignment is presented in the form of a music concert, in its presentation, composer tries to realize the integrity, shape, structure, and weight of the contents of the whole piece so that when the performance runs smoothly and the gending or the song that is perform can be performed well. In addition, what is also important in the success of the performance is the element of expression, inspiration, and songs soul that are sung.

Stage Costume is an element that is no less important than the other elements in the presentation of art performances, costumes also serve to support 
creativity reinforce the atmosphere in favor of ideas and concepts of the presented artwork. Ngemban Rare uses classic costumes tailored to the performing needs of the piece. In this piece uses a classic costume with a neutral white Kemben with a slightly prada-patterned floral pattern, using a light brown base udeng flower-colored endek fabric with a gold-emera motif, the same as the tassels used as well as using a scarf in color basic dark brown with a type of cloth endek. composer costumes different with rest of the players, because composer uses pegringsingan endek shawl that is used by the composer.

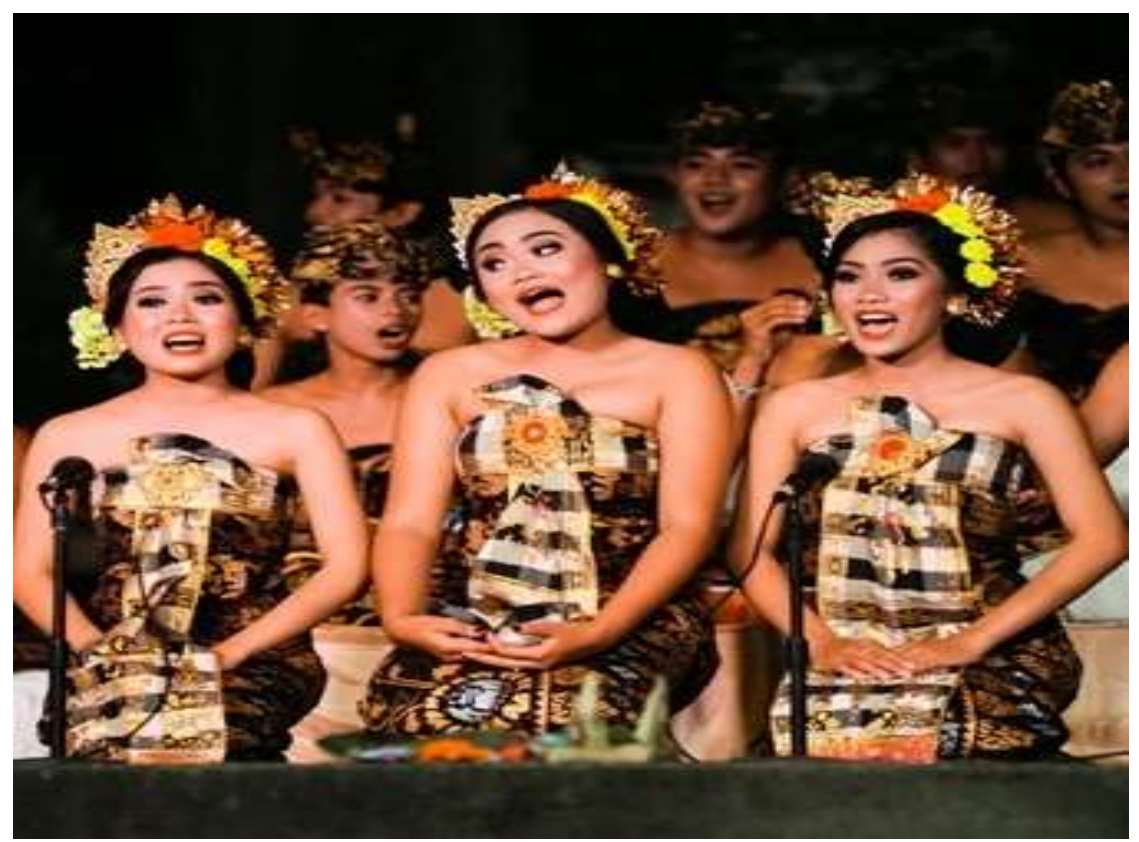

Picture 4.

Gerong Costumes of Ngemban Rare Piece 2018

(Documentation: Pande Kurnia Adnyana).

Gerong costume on this composition uses classic motifs with lelunakan containing gold and plastic flowers and petitis and also uses subeng, gerong using dark brown base color angkin with prada flower motif, using a black and white striped breastplate containing prada with floral motifs and using alpaca brooches with brass material. Gerong uses a dark brown kamben with prada floral motifs. Makeup is needed in the show to emphasize the facial expressions of the musicians and also supported by lighting with a minimalist staging concept, so that the messages Ngemban Rare can be conveyed to the audience. 


\section{CONCLUSION}

Ngemban Rare describes different ways of educating children in the past and today, which both have very different approaches on how to educate. These differences produce different children's characters. From this experience came the idea to realize thoughts into the composition of the percussion creations. The composer was inspired by the way parents used to be react, when a small child cried and was hard to calm, usually holding a child would most of the time sing traditional children's songs and even sing Balinese gamelan so that the child could calm down and fall asleep. Departing from this experience composer realized this music by applied it into three parts in the composition, there are the first part, the second part, and the third part. Composer negotiates the idea by using gamelan gong suling, because according to the composer, gamelan represent composer thoughts.

Ngemban Rare composition uses three parts to be realized, the first being part one, part two, and part three. In each section composer use the ilustration of something to describe each part, the instruments that will be used is the gamelan gong suling, and also with krumpungan drum instruments, timbung, ceng-ceng ricik, klenang, gong pulu, kajar pelegongan, and laughter. In the process of composition, composer also arranges and presents the fun in the music, so that is not boring when presented the music.

From the phenomena, composer makes this music concept in the form of percussion creations that use gamelan gong. Composer tries to raise the phenomenon of life inspired by the way parents in ancient times caring for children who were crying, and really very concerned about parents today who take care of their children in a way that is not good and damaging the character of children, from the phenomenon composer realizes the concept this with three parts.

In the first part, composer imagines how the child behavior who is still cute and adorable, which in everyday life is adorned with laughter and usually a small child curiosity about something so big. Sincere, innocent, cheerful and innocent like white paper that has not been touched by ink is the nature of small children. In the description of the musical language, we process jegogan and gong flutes and fill in the vocals that follow the melody.

The second part, describes how psychologically children have changed because they start to fuss and cry. Usually children get bored with the situation. 
Psycholigical change so quickly, in the second part is described a child who has been crying and hard to calm. Parents are struggling to carry and give milk to calm the child, in this part it raises a phenomenon that often occurs now where children who are not old enough have been facilitated by their parents excessively, this makes the character of the child is not good. This means more processing of harmony in the tone of the flute and also inserting vocals.

The third section, describes parents who are aware of how to educate thier children who are wrong and go back to using the ancient way parents used to educate children who are fussy. In part three, composer uses vocal or singing songs that seem to calm the crying child according to the experience of composer when he was a child. And also part three is the last part of the work or ending work, and in part three it asking parents to educate their children in a good way, do not provide anything or facilities before the child is old enough to instill good character.

\section{REFERENCES}

Agus, I. M; Antara, B; Sudirga, I. K; Santosa, H. 2018. "Cak Ganjur: Sebuah Komposisi Musik Vokal Gabungan Cak dan Balaganjur", Kalangwan Jurnal Seni Pertunjukan Volume 4 Nomor 2 (September), 96-104.

Djelantik, A. A. M. 1990. Pengantar Dasar IImu Estetika Jilid I. Denpasar: Sekolah Tinggi Seni Indonesia Denpasar.

Garwa, I. K. 2009. "Buku Ajar Komposisi Karawitan IV". Diktat Perkuliahan. Fakultas Seni Pertunjukan, Institut Seni Indonesia Denpasar.

Wiana, K. 1997. Cara Belajar Agama Hindu yang Baik. Denpasar: Dharma Naradha. 